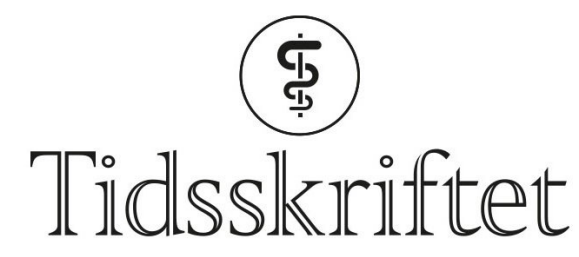

DEN NORSKE LEGEFORENING

\title{
Å ta på er å røre ved
}

MINILEDER

ARE BREAN

Sjefredaktør

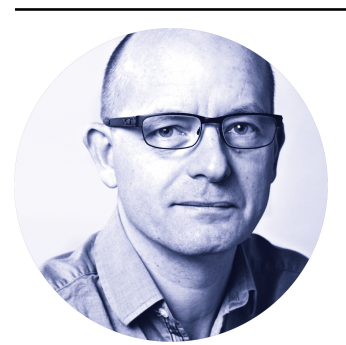

Digitale møter og konsultasjoner, hjemmekontor og manglende sosiale arenaer -

skjermbruk har nådd nye høyder under koronapandemien. Hva om du gjør et eksperiment denne påsken, og tar bare med deg fysiske bøker og tidsskrifter inn i fridagene, lesestoff du kan ta og føle på?

Da kan du jo begynne med det du holder i hendene nå: Tidsskriftets påskenummer på papir. En passende start er kasuistikken om nydiagnosen transitorisk smarttelefonblindhet (s. 457), før du tar en kikk på helsideannonsen på side 477: «Påskens cigarett er Blue Master». Slik kunne man nemlig annonsere for bare noen tiår siden, før epidemiologen Richard Doll (1912-2005) påviste røykingens sammenheng med lungekreft. Men kan hans forskning også lære oss noe om smarttelefoner? Les om dette fra side 476 . Påskekrimmen finner du i essayet «Sint nikkedukke - nevrologisk syndrom i en kriminalroman» (s. 472), hvor farmasøytisk industri inntar skurkerollen.

Og blant alt det andre stoffet: Årets påskeintervju er med Odd Martin Vallersnes (s. 468). Han har en gang skrevet: «Undervurder aldri betydningen av å ta på pasienten. Å ta på er å røre ved». Etter denne høytiden er det forhåpentligvis ikke lenge igjen før vi på ny kan ta på hverandre, både privat og profesjonelt. I mellomtiden håper vi at noe av stoffet i dette påskenummeret vil røre ved deg. Riktig god påske!

Publisert: 22. mars 2021. Tidsskr Nor Legeforen. DOI:10.4045/tidsskr.21.05.01

(C) Tidsskrift for Den norske legeforening 2020. Lastet ned fra tidsskriftet.no 